\title{
Opinion paper
}

\section{The CINMa Index: Assessing the potential impact of GM crop management across a heterogeneous landscape}

\author{
Marcus J. COLLIER and Ewen MULLINS * \\ Dept. Crop Science, Programme for Crops, Environment and Land Use, Teagasc Research Centre, Oak Park, Carlow, Ireland
}

\begin{abstract}
While significant progress has been made on the modification of crops for the benefit of producers, the same cannot be said in regards to eliciting the potential impact that these crops may have on the wider landscape and the diversity of life therein. Management impacts can create difficulties when making policy, regulation and licensing decisions in those countries where agriculture has a significant social and ecological position in the landscape. To begin to gauge the potential impacts of the management of a selection of GM crops on an agricultural landscape, four key biodiversity stressors (Chemicals, Introgression, Nutrients and Management: CINMa) were identified and a grading system developed using published data. Upon application to five selected GM crops in a case study area, CINMa identifies areas in the wider landscape where biodiversity is likely to be negatively or positively impacted, as well as agricultural zones which may benefit from the land use change associated with the management of GM crops and their associated post market environmental monitoring.
\end{abstract}

Keywords: biodiversity / CINMa / GM crops / landscape impact / oilseed rape / potato

\section{INTRODUCTION}

As the EU strives to meet the current and future demands for food/fuel security, species and habitat diversity in rural landscapes will be subjected to continual and increased stress (Sutherland et al., 2010). An urgent need exists therefore to mainstream sustainable agricultural and land management practices (Tilman et al., 2001, 2002). In order to monitor the possible ecological impacts, there is also a need to significantly augment, and ultimately harmonise, risk assessment strategies especially when technologies such as GM crops are incorporated into established agricultural landscapes (Sutherland et al., 2008). Under the terms of Directive 2001/18/EC (EC, 2001) post-market environmental monitoring of GM crops within the European Union (EU) must adopt both case specific monitoring and general surveillance (GS) strands of assessment. GS is intended to ascertain the possible unintended effects of a GM crop release, but is not adequately defined from a practical point of view (Bartsch et al., 2006; Sanvido et al., 2005). Wilhelm et al. (2009) discuss the difficulties of both types of assessment and call for the integration of the impact literature, field analysis and communication of risk to be drawn upon to provide a more realistic GS solution. In this paper

* Corresponding author: ewen.mullins@teagasc.ie we propose an assessment index which will begin to address the ambiguity centred on GS, while also facilitating a move towards the harmonisation of risk assessment approaches across the EU. Since heterogeneous landscapes consist of multiple elements, when seeking to make predictions on the future implications of a GM crop release it is judicious to isolate these elements and the stressors thereon. This paper explores the proposal of using an index of biodiversity stressors using case study research applied to the Irish agri-environmental landscape. Drawing primarily on GM crop research for illustration, the potential of this index will be discussed in relation to its wider use for alternative crop releases.

\section{BACKGROUND}

Many of the comparative studies describing the impacts of conventional cropping systems on rural ecology demonstrate the negative impact of crop production on biodiversity (e.g. O'Brien et al., 2008). The impact of GM crops on local species has also been extensively researched in some locations (Barton and Dracup, 2000; Dunfield and Germida, 2004; Sanvido et al., 2007; Turner, 2004), yet there is little evidence to link their cultivation to adverse biodiversity impacts at a local level (Ammann, 2005; Cerdeira and Duke, 2006). Much of 
the GM crop research completed thus far has focussed on issues such as crop co-existence (e.g. Petti et al., 2007; Schiemann, 2003), genetic introgression (e.g. Chandler and Dunwell, 2008) and volunteer dynamics (Owen and Zelaya, 2005), often in the context of the on-farm environment. Far less is known about the possible impacts of crop management (GM or non-GM derived) on the wider landscape.

Assessment of impact usually takes a species-centred approach, where indicator species are identified either individually or by holistic sampling (Hoffmann and Greef, 2003), with the European Food Safety Authority (EFSA) identifying, among other things, the need for unified methodologies and models (EFSA, 2010). Multi-scaled assessments that have been used for case specific monitoring have shown that it is difficult to distinguish the impacts from background conditions (Aviron et al., 2006). Overall, impact assessment research is fraught with the difficulty of identifying, from the outset, what is to be assessed, what an impact may be and where to look for this impact (Raybould, 2006). While there is the need to focus on GM crops in order to satisfy requirements, little attention has been focussed on non-GM crops and this imbalance (Sanvido et al., 2007) may have served to reinforce concerns on GM crop impact. It is generally accepted that GM crop farming may have similar impacts to non-GM crop farming (Conner et al., 2003) in relation to biodiversity stress in the wider agricultural landscapes. We believe that the impact of GM and non-GM crops can be jointly assessed using a broad index that encapsulates the management of both cropping systems and the corresponding stresses each may cause to landscape biodiversity. To test this theory and for purposes of illustration we have focussed on those GM crops with a high potential of uptake in the Irish agri-environment, where GM crops are de facto prohibited despite the high degree of acceptance by growers (Thorne et al., 2008), thus providing an ideal case study area.

\section{MODEL DESCRIPTION}

From the outset, numerous stressors were examined and used to inform the development of the index. To test impact, one must examine all aspects of land management such as crop rotations and treatments, crop type and variety and length of operations. While geography, biology and taxonomy are key areas of ecological impact (Byrne and Stone, 2011) and will exert stress on biodiversity, it was decided that such scalar stressors would be unmanageable on a practical level. Therefore, we use the four main areas where data are available and upon which farmers can exert the most control. The impact grading system underscoring our biodiversity impact index (CINMa) was designed around the four principle biodiversity stressors that GM (or conventional) cropping may have on the landscape.

\section{Chemicals (C)}

Agricultural activities are dependent on the use of a host of synthesised crop protectants. For the 19400 ha of crops grown in Ireland, around 1520 tonnes of formulated chemicals are applied each year (Department of Agriculture and Food, 2007). Chemical residues can occur as a result of over-use, misuse, storage and after-use of herbicides, pesticides and fungicides within a cropping area and throughout the landscape. There are numerous possibilities for un-intentioned contamination or release not only on the farm itself but also in the transport to the field and the removal from the farm (for disposal).

\section{Introgression (I)}

The potential for inter-species gene flow has caused concern in relation to the potential impact of GM traits on biodiversity (Snow, 2002; Stewart Jr. et al., 2003), and while Conner et al. (2003) point out that for some traits this is no more relevant to GM crops than non-GM crops, other traits such as nitrogen use efficiency (NUE) by their nature may well have an impact. The introgression of a GM trait into a related species may occur via hybridisation events with a feral population, a neighbouring crop, crop volunteers or wild relatives. Building on previous work (Flannery et al., 2005), the significant criteria adopted here is whether the hybrid population (arising from the $F_{1}$ ) is able to thrive and persist in the landscape for up to ten years (Lutman et al., 2004). In natural conditions, the rate of plant population increase $(\lambda)$ is usually stable (i.e. $\lambda=1$ ). It has been demonstrated that the novel traits of some crops, e.g. GM disease resistant sunflowers, will introgress into related weed species and proliferate therein $(\lambda>1)$ (Snow et al., 2003). In contrast, traits such as GM herbicide tolerant (HT) oilseed rape, have been shown to gradually diminish in weed species over time $(\lambda<1)$ (Warwick et al., 2008). Critically, the presence of hybrids do not necessarily indicate ecological alterations (Wilkinson et al., 2003) and it is known that they arise through natural processes (Ellstrand et al., 1996). So, while persistence is not necessarily predicated solely on a crop having a novel trait (Wilkinson and Tepfer, 2009), crop to wild relative introgression must be considered as a potential biodiversity stressor in light of future GM traits that could be commercialised (Sanvido et al., 2007). 
The CINMa Index: Assessing the potential impact of GM crop management across a heterogeneous landscape

\section{Nutrients ( $N$ )}

In 2008, 308960 tonnes of nitrogen, 26350 tonnes of phosphorous and 69584 tonnes of potassium were applied across the Irish landscape (Connolly et al., 2009; Lalor et al., 2010). Such a significant input warrants a separate stressor from other chemical inputs described earlier. While natural and synthetic crop fertilisers are a prerequisite for commercial crop production, the EU has attempted to mitigate their impact (EC, 2000; EEC, 1991). Less than $50 \%$ of field-applied nitrogen and phosphorous is assimilated by crop plants (Smil, 1999, 2000) and excess nutrient inputs have had an impact on landscape biodiversity (Swift et al., 1998), especially in aquatic systems (Kelly et al., 2007). In turn, this will impact on soil carbon ratios, ion exchange alteration and general nutrient loading, which can impact on nutrient cycling and contribute to acidification processes (Aherne et al., 2002). In addition, increased nutrient loads can flow to field boundaries and marginal areas of the farm (Viaud et al., 2004) and can give rise to virulent plant growth, often at the expense of other flora (Mette et al., 2001).

\section{Management (Ma)}

Farm management regimes have a high impact on the landscape (Büchs, 2007), locally by way of compaction and physical disturbance and on a wider scale by releasing emissions to air, soil and water. Such carbon fluxes may have a bearing on soil biodiversity in both a positive and negative sense (Anderson, 2003) and they may also have an impact on ecosystem services (Dale and Polasky, 2007) and soil processes (Laggoun-Défarge et al., 2008). Soil structural impacts also include recurrent compaction in gateways and drainage activities which in turn may change soil composition, impede the growth of roots, soil infiltration capacity and the availability of some nutrients. Traffic movements, vehicular disturbance, excavation and noise can contribute to direct and indirect species impact, despite the tolerance ability of some species (Håkansson et al., 1988). Other management activities will also impact on landscape biodiversity. For example, water (for equipment cleaning and chemical mixing) is sourced on many Irish farms, from aquifers as well as local watercourses, resulting in potentially negative impacts such as groundwater pollution (EPA, 2006; Taylor et al., 1983). The intensification of farming has also resulted in the removal of landscape features such as ditches and hedgerows as well as the draining or infilling of micro habitats such as field ponds (Petit et al., 2003), all of which place a high stress on landscape biodiversity.

\section{CINMa DESCRIPTION}

The CINMa index was designed as a semi-quantitative representation of a qualitative analysis of the literature (published and peer-reviewed material and expert-driven reports). Thus some of the underlying variables have been derived using ontologically different sources, landscape locations and experimental methodologies. The grades shown here were derived from sources with relevance to heterogeneous landscapes and allocated based on significance to Irish landscapes or species located within those landscapes. This approach is comparable to existing models (e.g. Breckling et al., 2011; Thompson et al., 2003) and is common in life cycle assessments that are used predominately in environmental impact statements, though Haas et al. (2000) caution that such assessments must specifically identify the impact area. To address this we identified four impact zones across a typical agricultural landscape (Fig. 1).

Each zone was assessed and graded with a negative $(-)$ /positive (+) linear scale, indicating that the net potential impact was considered to be negative/positive compared to an equivalent conventionally managed crop variety. Crops that are not currently commercialised were assessed on the basis of their specific trait in combination with current agronomic conditions. Hence, the impact of each of the four biodiversity stressors was graded from 2 ("high probability of impact"), through 1 ("low probability of impact") to 0 (indicating neutral impact and/or there are no relevant data for this scenario). The assigned scores were averaged over all four zones as if each had an equal biodiversity value, so as to afford a spatial "levelling field" and thereby permitting an holistic assessment at a landscape level which is the ultimate aim of GS, coupled with the fact that a generic GS is by nature undefined (Wilhelm et al., 2009). This implies that the stressors can have a "parity of impact", i.e. an equal weighting. This weighting is untested in real-world scenarios and it is not equally represented or researched in the literature. However, the spatial and temporal impacts of the four stressors across the four zones may ultimately amount to the same cumulative impact, and minor alterations in values may ultimately amount to the same practical outcomes. It is doubtful that a weighting system could be devised that is acutely sensitive to the complexity of impact issues, particularly in the timeframe envisaged for GS. In addition, it would not be possible without significant time and finances to identify a hierarchy of actual and relative landscape impacts. As the goal of the CINMa index is to simplify the process to a more manageable level, equal weighting is assumed, though not critically evident. Thus, a linear relationship is used here, though in time and with better understanding of the interrelationships in the landscape, this may evolve to more accurate calculations and transformations. 


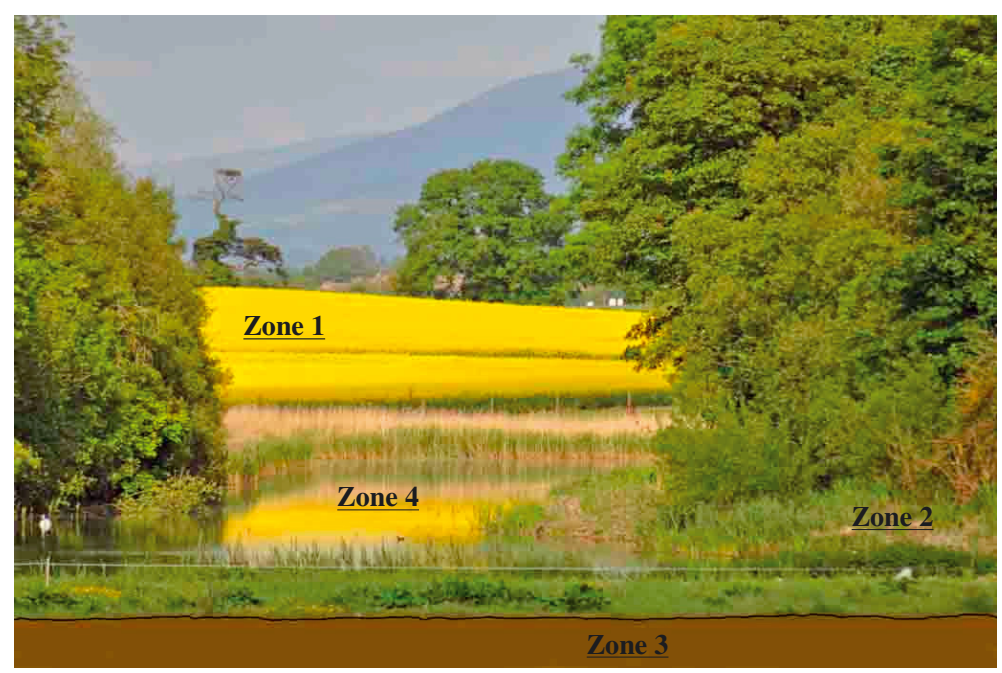

Figure 1. Illustration of the four landscape zones addressed within the CINMa index that encompass the managed field itself (zone 1), semi-natural landscape features (e.g. hedgerows, coppice, hay meadows, etc.) within $10 \mathrm{~m}$ of zone 1 (zone 2), the soil column (zone 3) and nearby water courses - drains, rivers or still water bodies as well as groundwater within the influence of zone 1 (zone 4 ).

\section{CINMa IMPLEMENTATION}

The methodology was applied to five GM crops, which have specific relevance to the Irish tillage sector (O'Brien and Mullins, 2009). The proposed scores for each crop following consideration of each stressor interaction with each zone are presented in Tables 1-5, with supporting rationale and literature described below each table.

\section{Genetically Modified Herbicide Tolerant (GMHT) oilseed rape (winter)}

Farm scale evaluations in the UK noted a small but nonsignificant reduction in weed biodiversity in the crop zone (Firbank, 2003) but the time of spraying would now favour diverse field "weeds" of wildlife value (Dewar et al., 2003). Beckie et al. (2006) contend that weed diversity has not declined as a result of weed tolerance and there is no evidence linking HT oilseed production and unrelated species evolution herbicide tolerance as a result of farm management (Ellstrand et al., 1999). A score of -1 for introgression (I) is allocated since in the Irish landscape it is possible for a non-native wild relative, Brassica rapa, to hybridise with oilseed rape (Brassica napus), though these hybrids are less likely to be selected for because semi-natural areas in Ireland are not, in reality, managed using herbicides, but unintentional drift may occasionally occur and so a precautionary -1 is allocated. However, there is a minimal impact on the seminatural zones. The benefits of GMHT crops are best realised through a no-plough system (Sanvido et al., 2007).
Therefore, it is likely that minimum tillage (min-till) or no-till regimes will suit these crops and their managers. This form of management can have a significantly beneficial impact on soil biodiversity (Holland, 2004) and thus, a score of +2 is allocated. Lower emissions and more precision management, combined with a wider window for spraying management, could have significant benefits to soil biota (Schloter et al., 2003) and higher levels of plant residues may act as buffers (Locke et al., 2008) as well as increase soil carbon. Indeed, the lowering of farm management activity may benefit some species in semi-natural habitats, but this has not been quantified. Impacts on watercourses are not fully quantified though glyphosate, being less toxic than products in current usage, may have a low impact on freshwater habitats (Cerdeira and Duke, 2006) but would be an improvement on existing herbicides in terms of toxicity and residual persistence (score of +1 ). The issue of nutrients is not relevant for this scenario.

\section{Genetically Modified Nitrogen Use Efficient (GMNUE) oilseed rape}

Yet to be commercialised, GMNUE oilseed rape has been developed through overexpression of the barley alanine aminotransferase, which has generated material requiring up to $40 \%$ less nitrogen to achieve yields equivalent to non-GM conventional varieties (Good et al., 2007). The cultivation of such a crop will lead to the introgression of the NUE trait into the interfertile relative, $B$. rapa, over time. While previous work indicates that introgressed 
The CINMa Index: Assessing the potential impact of GM crop management across a heterogeneous landscape

Table 1. CINMa scoring for GMHT oilseed rape.

\begin{tabular}{|l|c|c|c|c|l|}
\hline & C & I & N & Ma & \\
\hline Zone & & & & & $\begin{array}{l}\text { Mean zone } \\
\text { score }\end{array}$ \\
\hline 1 - Managed cropping area & 1 & -1 & 0 & 1 & 0.25 \\
\hline 2 - Semi-natural area & 0 & -1 & 0 & 0 & -0.25 \\
\hline 3 - Soil & 1 & 0 & 0 & 2 & 0.75 \\
\hline 4 - Watercourses & 0 & 0 & 0 & 0 & 0 \\
\hline Mean biodiversity stressor score & 0.5 & -0.5 & 0 & 0.75 & \multicolumn{1}{|l}{} \\
\cline { 1 - 4 } & & &
\end{tabular}

Table 2. CINMa scoring for GMNUE oilseed rape.

\begin{tabular}{|l|c|c|c|c|l|}
\hline & C & I & N & Ma & \\
\hline Zone & & & & & $\begin{array}{l}\text { Mean zone } \\
\text { score }\end{array}$ \\
\hline 1 - Managed cropping area & 0 & -1 & 1 & 0 & 0 \\
\hline 2 - Semi-natural area & 0 & -2 & 1 & 0 & -0.25 \\
\hline 3 - Soil & 0 & 0 & 2 & 0 & 0.5 \\
\hline 4 - Watercourses & 0 & 0 & 1 & 1 & 0.5 \\
\hline Mean biodiversity stressor score & 0 & -0.75 & 1.25 & 0.25 & \multicolumn{1}{|l}{} \\
\cline { 1 - 4 } & & &
\end{tabular}

traits into $B$. rapa can persist for 5 to 10 years, providing a weed population with enhanced nitrogen use efficiency will undoubtedly increase the population's rate of increase due to the inability of neighbouring species to compete, hence justifying a score of -2 . The lower level of nutrient application will be of benefit to all zones, and any wild relatives that acquire the NUE trait may become problematic in off farm areas (such as roadsides or rail lines) rather than in well managed hedgerows, where shading and vigorous perennials may be limiting factors. Because species diversity may be affected by excess nutrients (Forman and Baudry, 1984) and hedgerows can intercept nutrient flows (Le Cœur et al., 2002), a lower level of nutrient applications in the field may benefit hedgerow diversity. Thus, a score of +1 is allocated in zones 1,2 and 4 . A higher score of +2 is allocated to zone 3 since the likelihood of soil nutrient loading and potential eutrophic episodes should decrease. Finally, there could also be less management interference and use of water for mixing and equipment cleaning which could lessen the need for water use as well as reduce soil compaction, but NUE crops will not eliminate nitrogen and still require applications, though total nitrogen will decrease.

\section{GMHT maize}

Providing farmers with the ability to exert weed control outside of the strict "window of opportunity" in existing conventional maize may favour the in-field "weeds" (Firbank, 2003; Heard et al., 2003) that may be found in zone 1. A reduction in management activity will also imply a decrease in emissions (Forristal, 2008) and management disturbance, thus zone 1 scores are in the positive spectrum, as was shown in the FSEs (Champion et al., 2003; Weekes et al., 2007). There are no issues with the semi-natural habitats for the same reasons as discussed under Table 1. Also, as glyphosate becomes inert upon contact with the soil, this will likely lead to increased soil detritivore activity (Powell et al., 2009). The effects of glyphosate on soil micro-organisms in GM crops will be no different than those in non-GM systems (Krogh and Griffiths, 2007), but the change of management to a min-till regime should benefit the abundance and diversity of soil species. The introgression stressor recorded a zero across each of the four zones as no wild relatives of maize exist in Ireland, nor can maize thrive outside a managed environment.

\section{Genetically Modified Late Blight Resistant (GMLBR) potato}

Growing GMLBR potato (resistant to Phytophthora infestans) can be expected to reduce the number of spraying applications from up to 15 per growing season to approximately two applications per season, when included as part of a crop-specific integrated pest management strategy; thereby impacting positively on crop biodiversity due to reduced disturbance and chemical input (numbers of spray applications). Impact on seminatural areas will be minimal with the possible exception of reduced spray drift. For zones 3 and 4, there would be less likelihood of chemical build-up and the ensuing run-off or toxic accumulation, due to the significant decrease in the level of active ingredient applied to the crop. 
Table 3. CINMa scoring for GMHT maize.

\begin{tabular}{|l|c|c|c|c|l|}
\hline & C & I & N & Ma & \\
\hline Zone & & & & & $\begin{array}{l}\text { Mean zone } \\
\text { score }\end{array}$ \\
\hline 1 - Managed cropping area & 1 & 0 & 0 & 1 & 0.5 \\
\hline 2 - Semi-natural area & 0 & 0 & 0 & 0 & 0 \\
\hline 3 - Soil & 1 & 0 & 0 & 2 & 0.75 \\
\hline 4 - Watercourses & 0 & 0 & 0 & 0 & 0 \\
\cline { 1 - 4 } Mean biodiversity stressor score & 0.5 & 0 & 0 & 0.75 & \multicolumn{1}{|l}{} \\
\cline { 1 - 2 } & & &
\end{tabular}

Table 4. CINMa scoring for GMLBR potato.

\begin{tabular}{|l|c|c|c|c|l|}
\hline & C & I & N & Ma & \\
\hline Zone & & & & & $\begin{array}{l}\text { Mean zone } \\
\text { score }\end{array}$ \\
\hline 1 - Managed cropping area & 2 & 0 & 0 & 2 & 1 \\
\hline 2 - Semi-natural area & 1 & 0 & 0 & 0 & 0.25 \\
\hline 3 - Soil & 1 & 0 & 0 & 2 & 0.75 \\
\hline 4 - Watercourses & 1 & 0 & 0 & 1 & 0.5 \\
\hline Mean biodiversity stressor score & 1.25 & 0 & 0 & 1.25 & \multicolumn{1}{|l}{} \\
\cline { 1 - 2 } & &
\end{tabular}

There would be significantly less soil impact in zone 2 than in a comparable non-GM potato crop. In zone 3, with fewer emissions of particulates to watercourses as well as a diminished need for using local water supplies to clean equipment and dilute the mix, there is a potential for beneficial impact. There is no impact on nutrient requirements and there are no introgression issues because there are no wild or indigenous relatives of potato in Europe.

\section{GMNUE potato}

Up to 150 units of nitrogen.ha ${ }^{-1}$.annum ${ }^{-1}$ is required for growing potatoes in Irish soils (Teagasc, 2004). A NUE potato variety could reduce this significantly and thus have a net beneficial impact on the diversity of in-field "weed" species, as nutrient enrichment has been implicated in biodiversity loss (Haines-Young, 2009). While there will be reduced nitrogen application levels during the growing season $(+1$ under $N)$ it is unlikely that there would be a lowering of the application frequency owing to the biology of the potato crop. As established hedgerows (such as those that pervade the Irish agrarian landscape) can intercept nutrient flows and species diversity will be affected by excess nutrients, the lower application levels result in a positive scenario for seminatural areas. Inputs could be significantly less than those needed for cereals, thus lowering the impact of excess nitrogen on soil processes and, ultimately, watercourses where lessened nutrients ought to reduce the potential for eutrophic episodes.

\section{DISCUSSION}

Using indices to convey pathways has proven itself effective and illustrative in the area of gene flow to the wider local landscape (Devos et al., 2008, 2009; Flannery et al., 2005). However, concern over gene flow is just one aspect of the potential impact of the introduction of GM crops, especially where management regimes change with the particular trait and across different landscapes. With the possible increase in novel trait crops arriving on the market, there is a need to devise an integrated assessment of the potential impacts (positive and/or negative) of these crops on landscape biodiversity. In proposing an impact index for GM crops we deemed it necessary to adopt a holistic paradigm (Cockburn, 2002); one where management practices and the associated supporting activities have a role to play in impacting the wildlife and habitats of farmland. Adopting this approach the CINMa index was designed and applied to five GM crops. Cognisant of the need to simplify the process for policy- and/or decision-makers, it was necessary to average scores evenly across the four biodiversity stressors and give equal weighting to each of the impact areas. We acknowledge that this could be contested, and will therefore require more research. However, in order to illustrate the potential of this index for GS and how the individual tables may be used to transform the data, the following two tables contain summaries of CINMa score ranges for potential impact on the landscape (Tab. 6) and the four farming zones (Tab. 7).

For GMNUE oilseed rape, CINMa indicates that while there may be additional biodiversity stress applied to some semi-natural areas, the overall benefit from 
The CINMa Index: Assessing the potential impact of GM crop management across a heterogeneous landscape

Table 5. CINMa scoring for GMNUE potato.

\begin{tabular}{|l|c|c|c|c|l|}
\hline & C & I & N & Ma & \\
\hline Zone & & & & & $\begin{array}{l}\text { Mean zone } \\
\text { score }\end{array}$ \\
\hline 1 - Managed cropping area & 0 & 0 & 1 & 0 & 0.25 \\
\hline 2 - Semi-natural area & 0 & 0 & 1 & 0 & 0.25 \\
\hline 3 - Soil & 0 & 0 & 2 & 0 & 0.5 \\
\hline 4- Watercourses & 0 & 0 & 2 & 1 & 0.75 \\
\hline Mean biodiversity stressor score & 0 & 0 & 1.5 & 0.25 & \multicolumn{4}{|l}{} \\
\cline { 1 - 2 } & &
\end{tabular}

Table 6. Comparison of mean scores, illustrating potential GM crop impacts of biodiversity stressors (C, I, N, Ma).

\begin{tabular}{|c|c|c|c|c|c|c|c|c|c|c|c|c|c|c|c|c|c|}
\hline & \multicolumn{8}{|c|}{ NEGATIVE } & & \multicolumn{8}{|c|}{ POSITIVE } \\
\hline $\begin{array}{l}\text { CINMa } \\
\text { SCORE }\end{array}$ & 2 & 1.75 & 1.5 & 1.25 & 1 & 0.75 & 0.5 & 0.25 & $\overline{0}$ & 0.25 & 0.5 & 0.75 & 1 & 1.25 & 1.5 & 1.75 & 2 \\
\hline$\overline{\mathrm{OSR}-\mathrm{HT}}$ & & & & & & & & & & & & & & & & & \\
\hline OSR - NUE & & & & & & & & & & & & & & & & & \\
\hline Maize-HT & & & & & & & & & & & & & & & & & \\
\hline Potato- LBR & & & & & & & & & & & & & & & & & \\
\hline Potato- NUE & & & & & & & & & & & & & & & & & \\
\hline
\end{tabular}

Table 7. Comparison of mean scores, indicating the potential impact of GM crops on the four selected landscape zones.

\begin{tabular}{|c|c|c|c|c|c|c|c|c|c|c|c|c|c|c|c|c|c|}
\hline & \multicolumn{8}{|c|}{ NEGATIVE } & & \multicolumn{8}{|c|}{ POSITIVE } \\
\hline ZONE SCORE & 2 & 1.75 & 1.5 & 1.25 & 1 & 0.75 & 0.5 & 0.25 & $\mathbf{0}$ & 0.25 & 0.5 & 0.75 & 1 & 1.25 & 1.5 & 1.75 & 2 \\
\hline OSR - HT & & & & & & & & & & & & & & & & & \\
\hline OSR - NUE & & & & & & & & & & & & & & & & & \\
\hline Maize - HT & & & & & & & & & & & & & & & & & \\
\hline Potato- LBR & & & & & & & & & & & & & & & & & \\
\hline Potato-NUE & & & & & & & & & & & & & & & & & \\
\hline
\end{tabular}

altered management and lower nutrient inputs should have a net beneficial effect on the wider landscape. For GMHT oilseed rape, CINMa shows a modest potential benefit for soil organisms under the newer management regime that novel trait crops necessitate and facilitate. There is some belief that there may be some unrelated "weed" species evolution with lowering of herbicide diversity in farm management regimes, but this has yet to be shown to be a stressor on other species and habitats in rural landscapes. There are no chemical concerns in marginal habitats, soils or watercourses due to the low toxicity of glyphosate; hedgerows, waterways and roadsides in Ireland are not typically managed using herbicides hence for those GM oilseed rape (B. napus $\times$ B. rapa) hybrids that do emerge the absence of a selection pressure will ensure that the opportunity to increase in numbers because of trait introgression does not materialise. Still, using a precautionary approach a negative score was allocated. This scenario will be different for other landscapes where species differ or with more related species in the wild. It will also be different for other novel trait crops. For example, in the case of imidazolinone tolerant oilseed rape the concern would be its potential toxicity to soil and water organisms. It is clear, however, that both oilseed rape crops may have a wide range of impact and this should guide future GS policies.

For GMHT maize, CINMa yields a higher likelihood of this variety positively impacting upon biodiversity. Again it is in the area of management that the benefits accrue as well as in-field weed diversity due to altered timing of spray application. As with GMHT oilseed rape, there may be a similar issue with herbicide diversity loss and the potential for forced "weed" evolution. For GMLBR potatoes, CINMa reports a positive benefit from management regime change, though again there are no data on potential impacts on the typical semi-natural habitats such as hedgerows that may be found in heterogeneous landscapes. The practical reduction or elimination of farm traffic, tanker washing, chemical mixing, and soil compaction have a high likelihood of reducing biodiversity stress. However, the use of GMLBR potatoes will impose an evolutionary pressure on Phytopthora infestans to mutate, but this cannot be counted as a negative impact as it is known that $P$. infestans spontaneously mutates in response to 
conventional potato breeding strategies ${ }^{1}$. Nevertheless, GMLBR is in the advanced stages of trials and can be expected to be released in the near future. For GMNUE potatoes, CINMa shows a similar result and it is the only case where there may be a demonstrable benefit to seminatural habitats. As with all of the novel traits, there is a potential benefit to the biodiversity of the soil. This can be seen as being a positive step, because the biodiversity of soils, especially agricultural soils, has significant economic consequences locally and globally (Brussaard et al., 2007; FAO, 2002; Kuhlman et al., 2010).

From a standpoint of ecological complexity, this index does not differentiate between landscape elements and interactions. Nor does it discriminate between individual elements of landscape biodiversity. However, it does permit the formation of a baseline for the analysis of any novel traits in the agricultural landscape and under all agricultural management regimes, regardless of their regulation. This index also contributes to landscape planning (under the European Landscape Convention (Council of Europe, 2000)) as well as policy evaluations. Critically, the CINMa index will provide guidance when carrying out GS in order to target specific areas (zones) for more intensive surveillance across landscapes. We expect that scores will need to be adjusted over time as new data become available and that discussions on the validity or otherwise of the CINMa scores presented here will stimulate such investigations and/or highlight specific areas where the CINMa approach can be improved upon. One such area for exploration may be to examine the difference in CINMa scores within non-GM farming systems in order to contribute to the sometimes divisive debate on the ecological impacts of different farming systems.

As an indicator model, CINMa may be used to highlight gaps in impact awareness of all crops and reveal areas of contention and possible conflict in agrienvironmental systems. However, the index is reliant on the accuracy and validity of existing data, adequacy of research parameters and similarity of landscapes, and thus it indicates likely trends rather than specific measures. Therefore the index ought to be used as a scoping tool at the preliminary stage of biodiversity impact assessments as well as an ex post tool for testing predictions or GS. The CINMa index is not intended to be used to illustrate that GM crops can bring about a reversal of habitat and species decline in agricultural landscapes. It shows, however, that the GM crop management regimes have the potential for redressing some of the previous impacts on farm biodiversity, and this ought to be considered when planning and reviewing the policies governing the release of new crops.

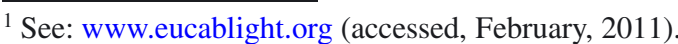

\section{CONCLUSIONS}

The authorisation process for GM crops in the EU has highlighted the importance and significance of impact assessments. However, an "impact" is challenging to quantify in its entirety and so it is necessary to adopt a wider viewpoint on the issue in order to make evidence-based assumptions that withstand scientific critique. A synthesis of research can be highly valuable when devising strategies for landscape conservation and some studies have extrapolated for data in similar landscapes (Reuter et al., 2011), or use landscape scale predictive modelling (Breckling et al., 2011). Much of the GM impact assessments rightly focus on vertical gene transfer, but there has been a deficit of attention to the potential impact on biodiversity at a landscape level. Though novel trait crops may not differ from similar varieties in their ecological impact no crop release can be impact free. Yet, as GM crops are "designed" to make farming more efficient it is logical to look for the impacts of altered management regimes when seeking to establish the potential impact on biodiversity. This has not been the case so far and thus there is a necessity to draw on as many discussions of the topic in order to provide research and management guidance to policy-makers, farmers and researchers.

The CINMa index presents a novel approach to gain an ex ante insight into the possible impacts of novel traits (GM or non-GM derived) on farm habitats, and as such provides a tool to regulators and researchers. While there are no data available on the actual impact, if any, of novel trait crops to on-farm habitats in Irish heterogeneous landscapes, the CINMa index addresses the absence of research specific to tillage landscapes. The index indicates that the potential impacts on biodiversity could largely be positive in tillage landscapes and that this can be attributed to the movement towards stricter and co-ordinated farm management regimes. With some case-specific modifications the index may be used to capture the potential impact of diverse crops, such as the afforestation of agricultural lands by novel trait tree crops. Compounding much of this discussion is the fact that agri-environmental impact research in tillage landscapes is minimal. We therefore propose that the CINMa index be considered as a predictive tool to direct future research endeavours or monitoring as novel trait crops become a more prevalent feature across European heterogeneous landscapes.

\section{ACKNOWLEDGEMENTS}

This research was funded by the Irish Environmental Protection Agency (ERTDI 2006-B-MS-46 and 2007-B-DS1-S1) and Teagasc, the Irish Agriculture and Food Development Authority. The authors would like to sincerely 
The CINMa Index: Assessing the potential impact of GM crop management across a heterogeneous landscape

thank the constructive comments and technical suggestions of the reviewers.

Received October 2, 2010; accepted February 19, 2011.

\section{REFERENCES}

Aherne J, Kelly-Quinn M, Farrell EP (2002) A survey of lakes in the Republic of Ireland: hydrochemical characteristics and acid sensitivity. Ambio 31: 452-459

Ammann K (2005) Effects of biotechnology on biodiversity: herbicide-tolerant and insect-resistant GM crops. Trends Biotechnol. 23: 388-394

Anderson T-H (2003) Microbial eco-physiological indicators to assess soil quality. Agric. Ecosyst. Environ. 98: 285-293

Aviron S, Sanvido O, Herzog F, Baudry J, Romeis J, Bigler F (2006) Monitoring effects of GM crops on butterflies: the use of multiscale approaches for general surveillance. J. Verbr. Lebensm. 1: 85-88

Barton JE, Dracup M (2000) Genetically modified crops and the environment. Agron. J. 92: 797-803

Bartsch D, Bigler F, Castanera P, Gathmann A, Gielkens M, Hartley S, Lheureux K, Renckens S, Schiemann J, Sweet J, Wilhelm R (2006) Concepts for general surveillance of genetically modified (GM) plants: the EFSA position. $J$. Verbr. Lebensm. 1: 15-20

Beckie HJ, Harker KN, Hall LM, Warwick SI, Legere A, Sikkema PH, Clayton GW, Thomas AG, Leeson JY, Seguin-Swartz G, Simard MJ (2006) A decade of herbicideresistant crops in Canada. Can. J. Plant Sci. 86: 1243-1264

Breckling B, Reuter H, Middelhoff U, Glemnitz M, Wurbs A, Schmidt G, Schröder W, Windhorst W (2011) Risk indication of genetically modified organisms (GMO): modelling environmental exposure and dispersal across different scales: oilseed rape in Northern Germany as an integrated case study. Ecological Indicators 11: 936-941

Brussaard L, de Ruiter PC, Brown GG (2007) Soil biodiversity for agricultural sustainability. Agric. Ecosyst. Environ. 121: $233-244$

Büchs W (2007) Impact of on-farm landscape structures and farming systems on predators. In David VA, ed, Biocontrol of Oilseed Rape Pests, pp 245-278

Byrne M, Stone L (2011) The need for "duty of care" when introducing new crops for sustainable agriculture. Current Opinion in Environmental Sustainability 3: 50-54

Cerdeira AL, Duke SO (2006) The current status and environmental impacts of glyphosate-resistant crops: a review. $J$. Environ. Qual. 35: 1633-1658

Champion GT, May MJ, Bennett S, Brooks DR, Clark SJ, Daniels RE, Firbank LG, Haughton AJ, Hawes C, Heard MS, Perry JN, Randle Z, Rossall MJ, Rothery P, Skellern MP, Scott RJ, Squire GR, Thomas MR (2003) Crop management and agronomic context of the Farm Scale
Evaluations of genetically modified herbicide tolerant crops. Philos. Trans. R. Soc. Lond. Ser. B 358: 1801-1818

Chandler S, Dunwell JM (2008) Gene flow, risk assessment and the environmental release of transgenic plants. Crit. Rev. Plant Sci. 27: 25-49

Cockburn A (2002) Assuring the safety of genetically modified (GM) foods: the importance of an holistic, integrative approach. J. Biotechnol. 98: 79-106

Conner AJ, Glare TR, Nap JP (2003) The release of genetically modified crops into the environment. Part II. Overview of ecological risk assessment. Plant J. 33: 19-46

Connolly L, Kinsella A, Quinlan G, Moran B (2009) National Farm Survey 2008. Teagasc, Athenry, p 108

Council of Europe (2000) European Landscape Convention. Council of Europe, Strasbourg, p 25

Dale VH, Polasky S (2007) Measures of the effects of agricultural practices on ecosystem services. Ecol. Econ. 64: 286296

Department of Agriculture and Food (2007) Pesticide Usage Survey: arable crops 2004 - Report No. 2. Stationary Office, Dublin, p 56

Devos Y, Cougnon M, Vergucht S, Bulcke R, Haesaert G, Steurbaut W, Reheul D (2008) Environmental impact of herbicide regimes used with genetically modified herbicideresistant maize. Transgenic Res. 17: 1059-1077

Devos Y, De Schrijver A, Reheul D (2009) Quantifying the introgressive hybridisation propensity between transgenic oilseed rape and its wild/weedy relatives. Environ. Monit. Assess. 149: 303-322

Dewar AM, May MJ, Woiwod IP, Haylock LA, Champion GT, Garner BH, Sands RJN, Qi A, Pidgeon JD (2003) A novel approach to the use of genetically modified herbicide tolerant crops for environmental benefit. Proc. R. Soc. Lond. B 270: 335-340

Dunfield KE, Germida JJ (2004) Impact of genetically modified crops on soil- and plant-associated microbial communities. J. Environ. Qual. 33: 806-815

EC (European Commission) (2000) Directive 2000/60/EC of the European Parliament and of the Council of 23 October 2000 establishing a framework for Community action in the field of water policy. Official Journal of the European Communities L 327: 1-72

EC (European Commission) (2001) Directive 2001/18/EC on the deliberate release into the environment of genetically modified organisms and repealing Council Directive 90/220/EEC. Official Journal of the European Communities: L 106/101

EEC (European Economic Community) (1991) Council Directive 91/676/EEC of 12 December 1991 concerning the protection of waters against pollution caused by nitrates from agricultural sources. European Economic Communities, Luxembourg

EFSA (European Food Safety Authority - GMO Panel) (2010) Guidance on the environmental risk assessment of genetically modified plants. EFSA Journal 8: 1879 
Ellstrand NC, Whitkus R, Rieseberg LH (1996) Distribution of spontaneous plant hybrids. Proc. Natl. Acad. Sci. U.S.A. 93: $5090-5093$

Ellstrand NC, Prentice HC, Hancock JF (1999) Gene flow and introgression from domesticated plants into their wild relatives. Annu. Rev. Ecol. Syst. 30: 539-563

EPA (Environmental Protection Agency) (2006) Environment in Focus 2006: Environment indicators for Ireland. Environmental Protection Agency, Wexford, p 116

FAO (Food and Agricultural Organisation of the UN) (2002) Soil Biodiversity and Sustainable Agriculture: paper prepared as a background paper for the Ninth Regular Session of the Commission on Genetic Resources for Food and Agriculture (CGRFA) FAO-Rome, 14-18 October 2002, Food and Agricultural Organisation of the UN, Rome, p 21

Firbank LG (2003) The Farm Scale Evaluations of springsown genetically modified crops - Introduction. Philos. Trans. R. Soc. Lond. Ser. B 358: 1777-1778

Flannery ML, Mead C, Mullins E (2005) Employing a composite gene-flow index to numerically quantify a crop's potential for gene flow: an Irish perspective. Environ. Biosafety Res. 4: 29-43

Forman RTT, Baudry J (1984) Hedgerows and hedgerow networks in landscape ecology. Environ. Manage. 8: 495-510

Forristal D (2008) Reduced fuel costs for tillage farmers. In Proceedings of the National Tillage Conference, 2008, Teagasc, Carlow, Ireland, pp 32-46

Good AG, Johnson SJ, De Pauw M, Carroll RT, Savidov N, Vidmar J, Lu Z, Taylor G, Stroeher V (2007) Engineering nitrogen use efficiency with alanine aminotransferase. Can. J. Bot. 85: 252-262

Haas G, Wetterich F, Geier U (2000) Life cycle assessment framework in agriculture on the farm level. Int. J. Life Cycle Assess. 5: 345-348

Haines-Young R (2009) Land use and biodiversity relationships. Land Use Policy 26 (Supplement 1): S178-S186

Håkansson I, Voorhees WB, Riley H (1988) Vehicle and wheel factors influencing soil compaction and crop response in different traffic regimes. Soil Tillage Res. 11: 239-282

Heard MS, Hawes C, Champion GT, Clark SJ, Firbank LG, Haughton AJ, Parish AM, Perry JN, Rothery P, Scott RJ (2003) Weeds in fields with contrasting conventional and genetically modified herbicide-tolerant crops. I. Effects on abundance and diversity. Philos. Trans. R. Soc. Lond. Ser. B 358 : $1819-1832$

Hoffmann J, Greef JM (2003) Mosaic indicators - theoretical approach for the development of indicators for species diversity in agricultural landscapes. Agric. Ecosyst. Environ. 98: 387-394

Holland JM (2004) The environmental consequences of adopting conservation tillage in Europe: reviewing the evidence. Agric. Ecosyst. Environ. 103: 1-25

Kelly F, Champ T, McDonnell N, Kelly-Quinn M, Harrison S, Arbuthnott A, Giller P, Joy M, McCarthy K,
Cullen P, Harrod C, Jordan P, Griffiths D, Rosell R (2007) Investigation of the Relationship between Fish Stocks, Ecological Quality Ratings (Q-Values), Environmental Factors and Degree of Eutrophication (2000-MS-4-M1). Environmental Protection Agency, Wexford, p 134

Krogh PH, Griffiths B (2007) ECOGEN-Soil ecological and economic evaluation of genetically modified crops. Pedobiologia 51: 171-173

Kuhlman T, Reinhard S, Gaaff A (2010) Estimating the costs and benefits of soil conservation in Europe. Land Use Policy 27: $22-32$

Laggoun-Défarge F, Mitchell E, Gilbert D, Disnar J-R, Comont L, Warner BG, Buttler A (2008) Cut-over peatland regeneration assessment using organic matter and microbial indicators (bacteria and testate amoebae). J. Appl. Ecol. 45: 716-727

Lalor STJ, Coulter BS, Quinlan G, Connolly L (2010) A Survey of Fertilizer use in Ireland from 2004-2008 for Grassland and Arable Crops (RMIS 5943 End of Project Report). Teagasc, Wexford, p 100

Le Cour D, Baudry J, Burel F, Thenail C (2002) Why and how we should study field boundary biodiversity in an agrarian landscape context. Agric. Ecosyst. Environ. 89: 23-40

Locke MA, Zablotowicz RM, Reddy KN (2008) Integrating soil conservation practices and glyphosate-resistant crops: impacts on soil. Pest Manage. Sci. 64: 457-469

Lutman PJW, Freeman SE, Pekrun C (2004) The long-term persistence of seeds of oilseed rape (Brassica napus) in arable fields. J. Agric. Sci. 141: 231-240

Mette R, Uckert G, Sattelmacher B (2001) A holistic approach towards sustainable land use management in the hedgerow-field crop interface. In Horst WJ, Schenk MK, Bürkert A, Claassen N, Flessa H, Frommer WB, Goldbach H, Olfs H-W, Römheld V, Sattelmacher B, Schmidhalter U, Schubert S, Wirén Nv, Wittenmayer L, eds, Plant Nutrition food security and sustainability of agro-ecosystems, Kluwer, pp 1026-1027

O'Brien M, Mullins E (2009) Relevance of genetically modified crops in light of future environmental and legislative challenges to the agri-environment. Ann. Appl. Biol. 254: 323-340

O'Brien M, Spillane C, Meade C, Mullins E (2008) An insight into the impact of arable farming on Irish biodiversity: a scarcity of studies hinders a rigorous assessment. Biology $\mathcal{E}$ Environment: Proceedings of the Royal Irish Academy 108 (B): 97-108

Owen MDK, Zelaya IA (2005) Herbicide-resistant crops and weed resistance to herbicides. Pest Manage. Sci. 61: 301-311

Petit S, Stuart RC, Gillespie MK, Barr CJ (2003) Field boundaries in Great Britain: stock and change between 1984, 1990 and 1998. J. Environ. Manage. 67: 229-238

Petti C, Meade C, Downes M, Mullins E (2007) Facilitating co-existence by tracking gene dispersal in conventional potato systems with microsatellite markers. Environ. Biosafety Res. 6: $223-235$ 
The CINMa Index: Assessing the potential impact of GM crop management across a heterogeneous landscape

Powell JR, Levy-Booth DJ, Gulden RH, Asbil WL, Campbell RG, Dunfield KE, Hamill AS, Hart MM, Lerat S, Nurse RE, Pauls KP, Sikkema PH, Swanton CJ, Trevors JT, Klironomos JN (2009) Effects of genetically modified, herbicide-tolerant crops and their management on soil food web properties and crop litter decomposition. J. Appl. Ecol. 46: 388-396

Raybould A (2006) Problem formulation and hypothesis testing for environmental risk assessments of genetically modified crops. Environ. Biosafety Res. 5: 119-125

Reuter H, Schmidt G, Schröder W, Middelhoff U, Pehlke H, Breckling B (2011) Regional distribution of genetically modified organisms (GMOs) - up-scaling the dispersal and persistence potential of herbicide resistant oilseed rape (Brassica napus). Ecological Indicators 11: 989-999

Sanvido O, Widmer F, Winzeler M, Bigler F (2005) A conceptual framework for the design of environmental postmarket monitoring of genetically modified plants. Environ. Biosafety Res. 4: 13-27

Sanvido O, Romeis J, Bigler F (2007) Ecological impacts of genetically modified crops: ten years of field research and commercial cultivation. In Fiechter A, Sautter C, eds, Green Gene Technology, Springer, Berlin, pp 235-278

Schiemann J (2003) Co-existence of genetically modified crops with conventional and organic farming. Environ. Biosafety Res. 2: 213-217

Schloter M, Dilly O, Munch JC (2003) Indicators for evaluating soil quality. Agric. Ecosyst. Environ. 98: 255-262

Smil V (1999) Nitrogen in crop production: an account of global flows. Glob. Biogeochem. Cycles 13: 647-662

Smil V (2000) Phosphorous in the environment: natural flows and human interferences. Ann. Rev. Energy Environ. 25: 5388

Snow AA (2002) Transgenic crops - why gene flow matters. Nat. Biotechnol. 20: 542

Snow AA, Pilson D, Rieseberg LH, Paulsen MJ, Pleskac N, Reagon MR, Wolf DE, Selbo SM (2003) A Bt transgene reduces herbivory and enhances fecundity in wild sunflowers. Ecol. Appl. 13: 279-286

Stewart Jr CN, Halfhill MD, Warwick SI (2003) Transgene introgression from genetically modified crops to their wild relatives. Nature 4: 806-817

Sutherland WJ, Bailey MJ, Bainbridge IP, Brereton T, Dick JTA, Drewitt J, Dulvy NK, Dusic NR, Freckleton RP, Gaston KJ, Gilder PM, Green RE, Heathwaite AL, Johnson SM, Macdonald DW, Mitchell R, Osborn D, Owen RP, Pretty J, Prior SV, Prosser H, Pullin AS, Rose P, Stott A, Tew T, Thomas CD, Thompson DBA, Vickery JA, Walker M, Walmsley C, Warrington S, Watkinson AR, Williams RJ, Woodroffe R, Woodroof HJ (2008) Future novel threats and opportunities facing UK biodiversity identified by horizon scanning. J. Appl. Ecol. 45: 821-833

Sutherland WJ, Clout M, Côté IM, Daszak P, Depledge MH, Fellman L, Fleishman E, Garthwaite R, Gibbons DW, De Lurio J, Impey AJ, Lickorish F, Lindenmayer D,
Madgwick J, Margerison C, Maynard T, Peck LS, Pretty J, Prior S, Redford KH, Scharlemann JPW, Spalding M, Watkinson AR (2010) A horizon scan of global conservation issues for 2010. Trends Ecol. Evol. 25: 1-7

Swift MJ, Andren O, Brussaard L, Briones M, Couteaux M-M, Ekschmitt K, Kjoller A, Loiseau P, Smith P (1998) Global change, soil biodiversity, and nitrogen cycling in terrestrial ecosystems: three case studies. Glob. Chang. Biol. 4: 729-743

Taylor HM, Jordan WR, Sinclair TR (1983) Limitations to efficient water use in crop production. American Society of Agronomy, Crop Science Society of America, Soil Science Society of America, Madison, p 538

Teagasc (2004) Farm Management Data Handbook. Teagasc, Carlow

Thompson CJ, Thompson BJP, Ades PK, Cousens R, Garnier-Gere P, Landman K, Newbigin E, Burgman MA (2003) Model-based analysis of the likelihood of gene introgression from genetically modified crops into wild relatives. Ecol. Modell. 162: 199-209

Thorne FS, Hanarahan K, Mullins E (2008) The Economic Evaluation of a GM Free Country: an Irish Case Study: RERC Working Paper 05-WP-RE-08, The Rural Economy Research Centre Working Paper Series, Teagasc, Carlow, p 37

Tilman D, Fargione J, Wolff B, D'Antonio C, Dobson A, Howarth R, Schindler D, Schlesinger WH, Simberloff D, Swackhamer D (2001) Forecasting agriculturally driven global environmental change. Science 292: 281-284

Tilman D, Cassman KG, Matson PA, Naylor R, Polasky S (2002) Agricultural sustainability and intensive production practices. Nature 418: 671-677

Turner R (2004) The field-scale evaluation of herbicidetolerant genetically modified crops conducted in the UK (1998-2003). J. Commercial Biotechnology 10: 224-233

Viaud V, Merot P, Baudry J (2004) Hydrochemical buffer assessment in agricultural landscapes: from local to catchment scale. Environ. Manage. 34: 559-573

Warwick SI, Légère A, Simard M-J, James T (2008) Do escaped transgenes persist in nature? The case of an herbicide resistance transgene in a weedy Brassica rapa population. Mol. Ecol. 17: 1387-1395

Weekes R, Allnutt T, Boffey C, Morgan S, Bilton M, Daniels R, Henry C (2007) A study of crop-to-crop gene flow using farm scale sites of fodder maize (Zea mays L.) in the UK. Transgenic Res. 16: 203-211

Wilhelm R, Sanvido O, Castanera P, Schmidt K, Schiemann J (2009) Monitoring the commercial cultivation of Bt maize in Europe - conclusions and recommendations for future monitoring practice. Environ. Biosafety Res. 8: 219-225

Wilkinson MJ, Tepfer M (2009) Fitness and beyond: preparing for the arrival of GM crops with ecologically important novel characters. Environ. Biosafety Res. 8: 1-14

Wilkinson MJ, Elliott LJ, Allainguillaume J, Shaw MW, Norris C, Welters R, Alexander M, Sweet J, Mason DC (2003) Hybridization between Brassica napus and B. rapa on a national scale in the United Kingdom. Science 302: 457-459 